\title{
The Anti-Corruption Stance of John the Baptist in Luke 3:12-14
}

\author{
Christopher NASERI* \\ • https://doi.org/10.31823/d.29.1.4 • \\ UDK: 27-247.7 • Preliminary Communication \\ Received: $18^{\text {th }}$ June 2020 • Accepted: $12^{\text {th }}$ February 2021
}

* Christopher Naseri, Ph. D., Faculty of Arts,

University of Calabar,

P. M. B. 1115 Calabar,

Cross River State, Nigeria

- St. Joseph Major

Seminary, P. M. B. 1039

Ikot Ekpene, Akwa Ibom

State, Nigeria,

paxcasa@yahoo.com

Summary: Luke 3:12-14 narrates John the Baptist's responses to the questions of the tax collectors and soldiers. These responses are interpreted in this work as measures against corruption. The text therefore provides an insight into unethical practices in the New Testament times, and the attempts by religious representatives to speak against them. Using the synchronic approach of historical critical method of exegesis this work concludes that the message of John the Baptist provides an insight into reasons for corruption among tax collectors and soldiers of the New Testament era. These reasons include 'not living within one's means' and 'not acting according to the law'. This work encourages religious representatives to speak out against corruption and be exemplary in their conducts.

Keywords: corruption, John the Baptist, soldiers, tax collectors, ethical question, civic responsibility, Gospel of Luke, salvation.

\section{Introduction}

Luke 3:12-14 narrates John the Baptist's incisive responses to the questions put to him by tax collectors and soldiers. The context of the text is John's preaching on repentance for the forgiveness of sins. He addresses the Jewish audience in preparation for the coming of the Messiah who was nationally expected by all. His message provokes in his listeners what may be termed a turning point question: 'what should we do?' Among the questioners are the toll collectors and soldiers of the Baptist's time. By the questions these workers wish to mutually discern through the help of the Baptist what God intends for them in their own occupation and what he wants of them in their profession. 
In response, John puts forward his ethical teaching that hits directly at the root of corrupt practices within the sphere of the people's profession. The responses of John are strictly speaking not religious, rather they border on economical or professional ethics. They are interpreted in this work as measures against corrupt practices among public servants. They indicate an underlying corruption among the law enforcement officers of the Baptist's time. The text therefore provides an insight into the reality of corrupt practices in the New Testament times, and the attempts by religious representatives to speak against them. Corruption is understood by the Transparency International as the abuse of entrusted power for private benefits and at the expense of the public good. This includes everyday abuse of power by public officials in their daily interactions with the ordinary citizens in the latter's attempts to access basic goods and services. It includes extortion, robbery, embezzlement, blackmail, and greed addressed by John the Baptist in the passage under consideration. These are issues bordering especially on the unethical conducts of the toll collectors and soldiers of the Baptist's time, and of public servants in contemporary societies. They are the consequences of people taking undue advantages of the opportunities available in their professions to exploit both the citizens and the state. They border on illegality, egoism, and disregard for the rule of law in the reckless exercise of public responsibilities.

The message of John the Baptist studied in this work provides an insight into reasons for these corrupt practices among tax collectors and soldiers of the New Testament era. These reasons include 'not living within one's means' and 'not acting according to the law'. These reasons also constitute the basis for corrupt practices in today's society. John's message, studied in the light of contemporary readers is therefore a call for people in today's society to live within the limits of their wages, and act within the law or with integrity. In their conducts and 'doings' they are invited to follow the dictate of their consciences and as Christians they are called to respond to the law and will of God as interpreted by the Christ they follow. It is an invitation to religious leaders and representatives and indeed all Christians to speak out against corruption and be exemplary too in their conducts. It is a demand on people in authority to understand their duty as service to the public and consequently remain accountable to the same public.

\section{Organization of the Text}

Generally, the pericope begins in v. 10 with the question from the crowd directed at John the Baptist and ends in v. 14 with the Soldiers and John the Baptist. The section is on the ethical preaching of John the Baptist in the light of social conduct. It is a question and answer session and on this basis it can be divided into: The Crowd 
and John the Baptist vv. 10-11, The Tax Collectors and John the Baptist vv. 12-13, and The Soldiers and John the Baptist v. 14.

The Crowd and John the Baptist vv. 10-11

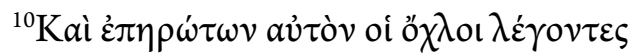

$\tau i$ ỡ $v \pi \circ \eta \dot{\sigma} \sigma \omega \mu \varepsilon v$;

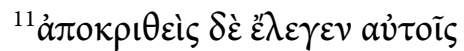

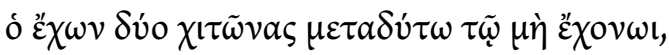

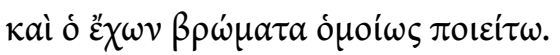

The Tax Collectors and John the Baptist vv. 12-13

${ }^{12} \tilde{\eta} \lambda \theta \circ \nu \delta \dot{\varepsilon} \tau \varepsilon \lambda \tilde{\omega} v \alpha \iota \mathrm{B} \alpha \pi \tau \iota \sigma \theta \tilde{\eta} v \alpha \iota$

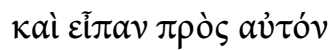

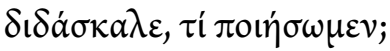

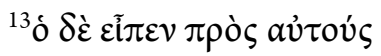

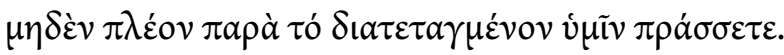

The Solders and John the Baptist v. 14

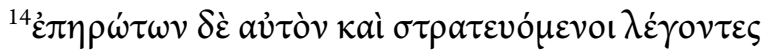

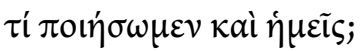

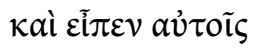

$\mu \varepsilon \delta \dot{\varepsilon} v \alpha \delta a \sigma \sigma \varepsilon \dot{\sigma} \sigma \eta \tau \varepsilon \mu \eta \delta \grave{\varepsilon} \sigma v \kappa o \varphi \alpha v \tau \eta \dot{\sigma} \sigma \eta \varepsilon$

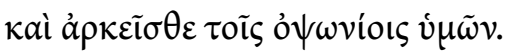

While verses 10-11 border essentially on the premise of charity, verses 12-14 underscore the theme of corruption. The attention of this study is only on verses 1214 ; the reason is essentially to allow the author to concentrate specifically on John's response to the question of corruption in relation to the tax collectors and soldiers of his time. The unit is thus divided into: The Tax Collectors' Question v. 12, John the Baptist's Response to the Tax Collectors v. 13, The Soldiers' Question v. 14a, John the Baptist's Response to the Soldiers v. 14b.

\section{Textual Issues}

There is no noticeable textual problem with the text except some occurrences in vv. 10, 12 and 14. In v. 10 manuscripts $\mathbf{D}$ adds $i v \alpha \sigma \omega \theta \omega \mu \varepsilon v$ while some uncials $\mathbf{b}, \mathbf{q}$ $\mathbf{v g}^{\mathrm{mss}} \mathbf{s a}^{\mathrm{mss}}$ use $\pi \circ \iota^{\prime} \zeta \omega \mu \varepsilon v$ rather than $\sigma \omega \mu \varepsilon v$. In v. 12 manuscript $\mathbf{D}$ adds $i v \alpha \sigma \dot{\omega} \theta \omega \mu \varepsilon v$ to the question. In v. 14 some manuscripts reverse the order of the question thus: 


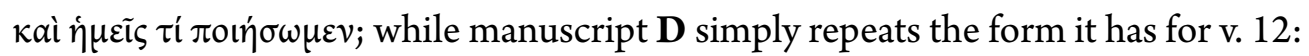

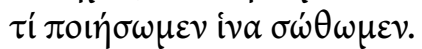

\section{John the Baptist, Tax Collectors, and Soldiers}

John the Baptist is a figure introduced in Luke 3:1-4, based on Luke's dependence on Mark 1:1-11. He is represented as a prophet anointed by God from birth to bring forth the renewal or transformation of the disposition of his people towards God and their neighbours. The repercussion of his ministry on human history is implied in Luke's collocation of his prophetic vocation with the personalities of Roman and Palestinian history. ${ }^{1}$ Tax collectors and soldiers come to be baptized in response to the preaching of John the Baptist. This preaching as laid out in vv. 3-9 is on repentance, Baptism, and the forgiveness of sins in expectation of the coming of the Messiah. It is an invitation to a renewal or change and a warning on the consequences of refusal to reform. It is, according to Josephus in his Antiquities an exhortation $\gg$ to live upright lives, in dealing justly with one another and submitting devoutly to God, and to join in Baptism «. ${ }^{2}$ Baptism, or Baptisma in Greek denotes $\gg$ the ceremonious use of water for purposes of renewal or establishing a relationship with God $\ll{ }^{3}$ It could take the form of plunging, dipping or washing and is an extraordinary encounter likened to an initiatory purification rite. John's Baptism of repentance for the forgiveness of sin therefore denotes a ritual washing, which like the Essene ritual washing implies the desire to 'turn from evildoing. ${ }^{4}$ It was a means of preparation for the expected salvation in Jesus. The tax collectors are specifically described in v. 12 as coming to John to be baptized; this same purpose would inform the coming of the soldiers in v. 14. The coming of these two groups of law enforcement agents to meet John and consequently receive baptism is therefore based on their conviction on the need to turn from their perceived wrongdoings and embrace an upright life. It is this desire that informs their question; 'what must we do'?

\subsection{The Tax Collectors v. 12}

The term $\tau \varepsilon \lambda \omega \nu \eta \varsigma$, which denotes tax collectors or revenue officers, is used in Luke and in the other Synoptics to refer to the subordinates of the tax farmers or holders

${ }^{1}$ Joseph Fitzmyer, The Gospel according to Luke 1-10 (New York: Doubleday, 1970), 453.

${ }^{2}$ Josephus, Antiquities 18. 5, 2, S\$ 116-119.

${ }^{3}$ Walter Bauer, et. al., » ßá $\tau \tau \iota \sigma \mu \alpha \ll, A$ Greek English Lexicon of the New Testament and Early Christian Literature, $3^{\text {rd }}$ ed. (Chicago: University of Chicago Press, 2000), 165.

${ }^{4}$ Essene Rule of the Community: Qumran Scroll IQS 5: 13-14. See also Joseph Fitzmyer, The Gospel according to Luke 1-10, 459 \& 460. 
of the contract to collect taxes on behalf of the authority. The Hebrew word for it is Môkěsin. While the holders or chief tax collectors were predominantly foreigners, wealthy Romans, the subordinates hired by them were as a rule, from the local communities. ${ }^{5}$ They were therefore Jews who collected tolls from different parts of Palestine for the Roman authority. J. Fitzmyer however, argues that the term tax collector does not adequately translate $\tau \varepsilon \lambda \omega \nu_{\eta} \varsigma$, he proposes 'toll collectors'; those responsible for the collection of indirect taxes like tolls, tariffs, imposts, and customs. ${ }^{6}$ The two terms are however, used interchangeably in this work. The system of tax farming performed by the tax collectors was flawed by many possibilities for unfair practices arising from greed. Numerous Aramaic and Greek ancient inscriptions record attempts by governments to put it in check. ${ }^{7}$ Tax farming implied a contractor paying the Roman authority in advance an estimated amount expected from indirect taxes like customs and tolls. The contractor who was called

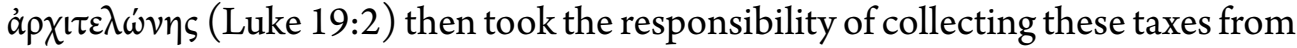
the people in the course of the year. To get the outsourced taxation it was also probable that the prospective toll collectors needed to provide the officials with more than the expected amount.

There was always a stipulated interest due to the contractors, which they were not authorised to exceed. There was, however, the tendency for abuses and consequently over taxation at the detriment and displeasure of the ordinary citizens. ${ }^{8}$ $\gg$ The system (of tax farming) had the disadvantage that the farmers had to impose more taxation than would be paid to the city in order to make an adequate profit and were thus driven over-readily to unlawful practices $\ll .{ }^{9}$ These were always frustrating for the citizens who as a result were negatively disposed towards tax officers. While the chief tax collectors or tax farmers would easily seek to collect excess taxes to make more than commensurate gains, their subordinates would in turn want to make their own gains. These greedy activities weighed heavily on the people and amounted to extortion.

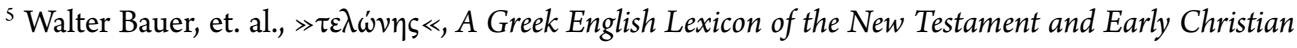
Literature, 999.

${ }^{6}$ Joseph Fitzmyer, The Gospel according to Luke 1-10, 469.

${ }^{7}$ John R. Donahue, »Tax Collectors and Sinner: An Attempt at an Identification, « CBQ33.1 (1971), 39-61.

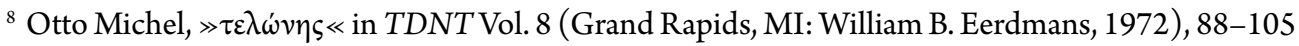
(100); see also I. Howard Marshall, The Gospel of Luke: A Commentary on the Greek Text (Grand Rapids, MI: William B. Eerdmans, 1978), 143.
}

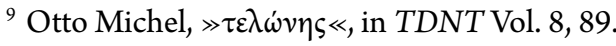


The collection of these tolls equally exposed the officials to ritual uncleanness arising from contacts with gentiles. Their profession was marked by entrenched, systemic injustice and they were judged to be involved in an institutionalized system of extortion or robbery that was unchecked. They were therefore judged by public opinion especially among pious Jews as dishones $\mathrm{t}^{10}$ and unrighteous and as rejected by God. They were however welcomed by Jesus and John (Luke 5:30$32 ; 7: 29)$. They came to John to receive his baptism of repentance in response to John's exhortation. This quest for John's baptism implied an acknowledgment on their part of the need to amend their ways. Their profession was equally numbered among those regarded as sinful; according to Otto Bauernfeind, they were seen as Jews who had made themselves Gentiles by entering into the services of a foreign oppressor.

$\gg$ The 'tax collectors' are sinners in this third category. The animosity toward them in the Gospels, mirrored in the various collocations of tax collector and robber (Luke 18:11), tax collector and harlot (Matt 21:32) and tax collector and Gentile (Matt 18:17), arises from a hatred for those who have betrayed their people by becoming as Gentiles. ${ }^{11}$

\subsection{The Soldiers v. 14}

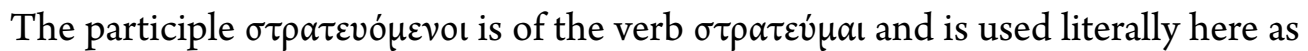
a substantive to refer to an $\gg$ individual on military service $\ll^{12}$. Though the definite article is absent, it is used substantively, and thus implies 'enlisted soldiers.' ${ }^{13}$ Luke does not specify if they were Jewish or Gentile soldiers. They were, however, not Roman Soldiers but Jewish men who enlisted in the military service of Herod Antipas and stationed in Peraea as mercenaries. Citing Josephus' Anthology 17:198f, Howard Marshall suggests that they possibly included non-Jews, or were Jewish auxiliaries engaged in Judaea for policing, and with M.-J. Lagrange he holds that they may have been enlisted to complement the services of the tax-collectors. ${ }^{14}$

During the New Testament times, there were constant conflicts and revolts within territories under the Roman Empire. There were constant deployment of sol-

\footnotetext{
${ }^{10}$ John R. Donahue, $\gg$ Tax Collectors and Sinner: An Attempt at an Identification $\ll, 59$.

${ }^{11}$ Ibid., 40.

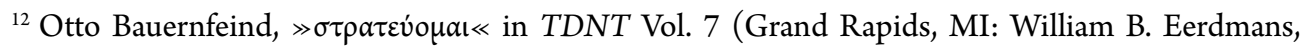
1971), 701-713 (703).

${ }^{13}$ F. Blass and A. Debrunner, A Greek Grammar of the New Testament and Other Early Christian Literature $4^{\text {th }}$ ed. Robert W. Funk (Trans.) (Cambridge: Cambridge University Press, 1961), art. 413:1, 212-213.

${ }^{14}$ I. Howard Marshall, The Gospel of Luke: A Commentary on the Greek Text, 143.
} 
diers and engagement of the services of mercenaries for the maintenance of law and order. Herod in his turn often appealed to Rome for help. At the heart of these tensions were the brutality of the soldiers, provocative and violent use of force, coercion, blood shed and loss of lives. ${ }^{15}$

$\gg$ Military intervention when it came was heavy-handed and often bloody. Inevitably, soldiers were treated wearily, with fear, distrust and dislike. Ancient sources in general depict the soldiers as despotic (...). The parable of how one should react when pressed to carry a pack for a mile (Matt 5:41) symbolizes the common perception of the petty tyrannies of the military. $\ll{ }^{16}$

The warning by Josephus that troops should desist from theft, rape and extortion confirms the prevalence of the practice of extortion on the part of the soldiers. ${ }^{17}$ Their allowance was generally insufficient; and like the toll collectors, there was the general tendency for them to seek to supplement their pay through these foul means by exploiting their victims. The reference to soldiers being bribed in Matthew 28:12-15 tells the story of their greediness. This possibility for unaccounted income was equally attractive for would-be employees while at the same time damaging and distasteful to the victims of the exploitations. Socially, the soldiers provoked fear and distrust among the inhabitants.

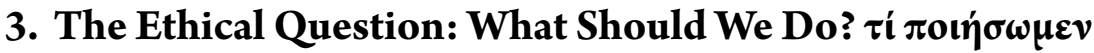

Tax Collectors: What should we do?

The Soldiers: What should we do, even we?

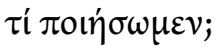

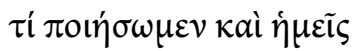

The two sets of questions reflect the same formula of questions directed at John the

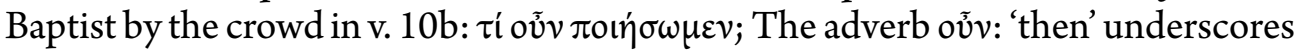
the function of the question as consequent on the activities of John the Baptist and its influence runs through the two subsequent questions. The questions are a miniature of questions that will dominate the Lucan narrative regarding the appropriation of salvation directed at Jesus by his would-be followers: $\gg$ What must I do to be saved « (Luke 10:25; 18:18; Acts 16:30b). The questions are »used by Luke as a stereotype phrase in his pattern of conversion (cf. Acts $2: 37 ; 16: 30 ; 22: 10) \ll{ }^{18}$

\footnotetext{
${ }^{15}$ David Kennedy, »Roman Army «, in David Noel Freedman (ed.), The Anchor Bible Dictionary Vol. 5 (New York, N.Y: Doubleday, 1992), 789-798 (794).

${ }^{16}$ Ibid., 794.

${ }^{17}$ Josephus, Life 244; The Jewish War 2. 581.

${ }^{18}$ Hans Conzelmann, The Theology of Luke, Geoffrey Buswell (Trans.) (London: Faber and Faber, 1961), 102.
} 
In each case it is preceded by a provoking encounter with a preaching, or a miraculous event in an immediate co-text. It underscores the function of this introductory narrative in the entire Lucan corpus that sets out to educate on the imperative of a response in the face of God's redemptive intervention in human affairs. ${ }^{19}$ They are requests to know how to bear 'the fruits of repentance' demanded in 3:8.

The soldiers' question on the other hand, is followed by the almost redundant phrase, кaì $\eta \mu \varepsilon ı$, , which denotes an emphasis. The toll collectors' question is preceded by the title $\delta 1 \delta \alpha \sigma \kappa \alpha \lambda \varepsilon$ which they use for John. It means 'teacher' and in relation to the Baptist, it is equated with Rabbi as is used in Luke 2:46. It is a form of address often used for Jesus by non-disciples in Luke (7:40; 19:38 et al.). It is used here as honorific title to recognize John as a teacher capable of expounding the divine will in the manner laid down by the Law and the Prophets and in a position to direct them to God. As $\delta เ \delta \dot{\alpha} \sigma \kappa \alpha \lambda$ o he is $\gg$ one who indicates the way of God from the Torah $\ll{ }^{20}$

\section{Deeds over against Speech or Hearing or Insignificant Action}

The term $\pi$ or $\varepsilon$ is used in this context especially to underscore the importance of deed over against mere speech or hearing or 'insignificant actions. ${ }^{21}$ It underlines in the Greek world how far human activities constitute what is good or what is bad in its relationship with God. From the context of the platonic use of the Orphic myth of judgement it embraces the extent to which humans must conduct themselves while alive or prior to death to determine what will become of the soul at judgement. In other words, $\gg$ what the soul has to strive for prior to death, namely, a healthy and even state which is not influenced either way by individual $\pi \rho \dot{\alpha} \xi \varepsilon \mid \varsigma_{{ }^{2}}{ }^{22}$ It underscores not principally a person's mode of conduct but the individual's apprehension of the sense of the good; the distinction between righteous teaching

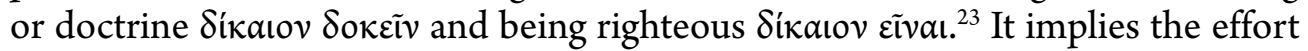
at realising the good. The general understanding in the Old and New Testaments is that human actions are subject to the prescriptions of Yahweh (Luke 10:28). These include the $\pi$ oi $\varepsilon v$ towards one's neighbor. $\gg$ Human work is never neutral;

\footnotetext{
${ }^{19}$ Joel B. Green, The Gospel of Luke (Grand Rapids, MI: William B. Eerdmans, 1997), 177.

${ }^{20}$ Karl Heinrich Rengstorf, $\gg \delta เ \delta \alpha \dot{\sigma} \sigma \alpha \lambda \lambda_{\circ} \ll$ in TDNT Vol. 2 (Grand Rapids, MI: William B. Eerdmans, 1964), 148-165 (152-3).

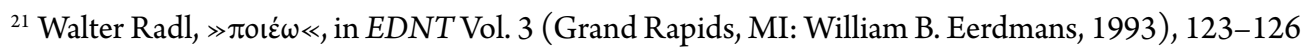
(125).

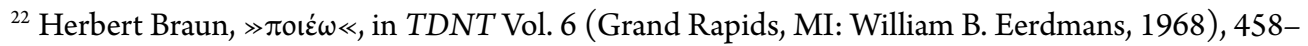
484 (465).

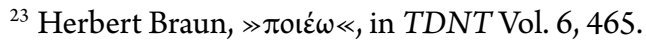


it is either obedience or disobedience vis-à-vis God's claim on men (1 Cor 10:31 'whatever you do, do all to the glory of God') « ${ }^{24}$ The most noble responsibility of the average Jew in the time of Jesus was to act according to the Law (Luke 2:27), thus in the question of 'doing' referred to here in Luke 3, the intent is on how the tax collectors and soldiers are to align their behaviours with the Law in which is contained the divine will.

This forms the basis for Yahweh's questioning of the action of Eve (Gen 3:13) and Cain (Gen 4:10). These questions regarding human action in Luke 3:10, 12 \& 14, which are instigated by the movement of conversion and directed at John the Baptist are in the context of his preaching about the Messiah. They are occasioned by the Jesus effect and are preparatory to their subsequent upgrading in the Lucan depiction of the ministry of Jesus to what humans are commanded to do to attain salvation (Luke 10:25). It lays the foundation for the Lucan discipleship as entailing doing what Jesus teaches. It implies that being with or of Jesus demands doing what he teaches (Luke 6:46). The questions in context can be understood as 'what should we do in repentance, to be part of the coming Messiah and consequently inherit eternal life.' The question 'what then shall we do' implies in this context of Luke 3:10,12, 14 the quest to give adequate attention to deeds as fulfilling the will of God over against mere speaking or hearing or less responsible actions (cf. Luke $6: 46,47,49 ; 8: 21$; Matt 7:21,22, 24,26).

It is a question about doing or performing, acting, against inaction in relation to what is right, as against that which they have been doing which was made evident in John's preaching as wrong. What should we do right against that which we have until now been doing wrong. It is an open acknowledgement of faults in an appreciation of a rebuke and the desire to amend. It is about action in relation to that which is heard; a follow up to the message of Jesus in Luke 6:46, 47, 49, 8:21. It re-echoes the lawyer's question to Jesus on what should be done to inherit eternal life in Luke 10:25, 28, 37. Interestingly, the doing at the end of the converse is about a neighbour as is implied in John's response, which centres mostly on social and civic responsibilities. The worth of actions is primarily based on the love for one's neighbour.

The question arises therefore from being challenged by the preaching of John, they become conscious of their wrongdoings, and ask 'what should we do'. It is an ethical question that implies recognition of error and the need for correction and improvement, the way forward and the implied willingness to make amends. By asking him the question, the people acknowledge that by his friendship with God as a teacher

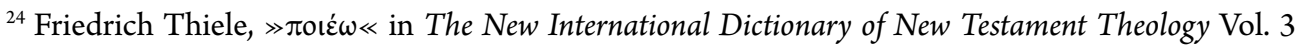
(Grand Rapids, MI: Zondervan, 1978), 1152-1155 (1155). 
the Baptist is in a position to give them the proper direction on pleasing God and finding favour on the side of God. At this point the vocative $\delta เ \delta \dot{\alpha} \sigma \kappa \alpha \lambda \varepsilon$ addressed to John stands out; to have been able to get his listeners to the level of asking the question indicates how effective a Rabbi the Baptist was and how pricking his message was. It marks the effectiveness of John's discourse or teaching as a teacher.

\section{The Ethical Teachings of John against Corruption}

The responses of John the Baptist to the questions by the toll collectors and soldiers are ethical and border on the extension of the demands of religion to the sphere of economics and social interactions. It is a teaching against extortion, robbery, embezzlement and greed, a teaching against corruption.

\subsection{EXTORTION}

»Exact no more than is appointed you $\ll$ v. 13

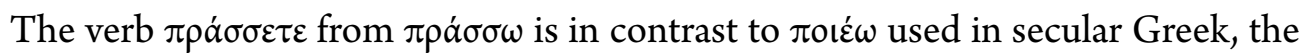
LXX and in the NT with humans rather than God as subjects. It therefore refers only to human actions, and the NT uses it mostly in contexts where these actions are judged negatively. ${ }^{25}$ It means 'to bring about or accomplish something through activity' (Luke 22:23; 23:15, 41). It has a sense of business, which often attracts an ethically negative implication and is thus too weak to embrace in the LXX the creative work of God or the strictly human action of personal obedience to God. ${ }^{26}$ It is used mostly in the LXX to describe bad behaviours of humans (Job 36:23; Prov. 10:23; Gen 31:28). In the NT, »it chiefly denotes a negative and more or less abstractly conceived human action; but in some places it is also used for positive dealings, or has a neutral value $\ll \cdot{ }^{27}$ In the context of Luke $3: 13$, it is used with the sense of 'extortion' to imply 'to collect taxes, duties or interest', 28 'to exact'.

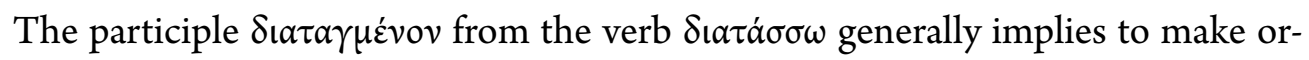
derly arrangements that enhance officially defined objectives. To give detailed in-

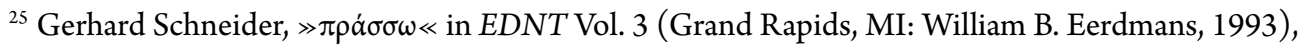

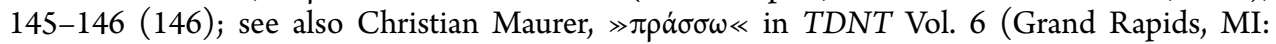
William B. Eerdmans, 1968), 632-438 (635).

${ }^{26}$ Christian Maurer, $\gg \pi \rho \alpha \dot{\sigma} \sigma \omega \ll$ in TDNT Vol. 6, 634.

${ }^{27}$ Hans-Christoph Hahn, » $\rho \alpha \dot{\sigma} \sigma \sigma \omega \ll$, in The New International Dictionary of New Testament Theology Vol. 3 (Grand Rapids, MI: Zondervan, 1978), 1155-1158 (1157).

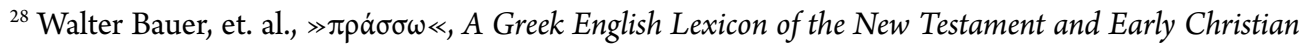
Literature, 860. 
structions or order regarding what must be done. ${ }^{29}$ It implies ordinances from a superior institution or authority like the state (Acts 18:2), God or Jesus (Luke 8:55). The preposition $\pi$ a à is used in the comparative sense here to denote 'beyond', 'in comparison to' or 'than' (Luke 13:2, 4; Rom 14:5). The comparative degree adjective $\pi \lambda \dot{\varepsilon} \circ v$ from $\pi \circ \lambda v^{\prime}$ (which denotes a 'large quantity') also means in the comparative sense 'more than'. With $\mu \eta \delta \varepsilon \dot{v} v$ the phrase $\mu \eta \delta \varepsilon \dot{v} v \pi \lambda \varepsilon$ 'ov means 'no more than' (see also Acts 15:28). The apparent redundancy occasioned by the use of $\pi \alpha \rho \alpha$ and $\pi \lambda \varepsilon \dot{v} v$ in the same phrase therefore serves to enforce the Baptist's emphasis on the 'more than' or 'beyond' the appointed rate. This introduces the sphere of the law; a society is to be ordered and held together for a healthy interaction among its members through laid-down and enforceable and respected laws. The absence of or disregard for such laws breeds chaos, fear, uneasiness, and underdevelopment. Under such laws there is a recommended rate for various tolls approved for toll collectors to work with; any rate beyond such lawfully stipulated rate is a violation of the law and extortion.

John is thus teaching the tax collectors to, as a matter of urgency, abstain from exacting or collecting more than that which, by the law of the state they are authorized to collect. Anything more is extortion, and a violation of the law. It is a call to act by the rule of law. It is an exhortation to be legally minded as officials of the state in the exercise of their daily responsibilities and to abstain from breaking the law. They are advised against padding the tax bills for the purpose of pocketing the excess. The emphasis here is not on 'what the toll collectors should do' but on 'what they should not do'. As agents of the state, they are all too familiar with the details surrounding their services more than the ordinary citizens on the street whose responsibility it is to make the payments. Most times, the agents of the state take advantage of their familiarity with the law against the ignorance on the part of the common citizens to exploit and extort from them. 'What they should do' is collect the tolls, 'but what they should not do' is 'collect beyond the stipulated rates'. In this case 'what they should not do' still falls within the realm of 'what they should do' of v. 14 because the decision to 'not do' is in itself an act or a 'doing'

\subsection{Robbery, EmbezZlement, Blackmail and Greed}

$\gg$ Rob no one by violence or by false acquisition, and be content with your wages « v. 14.

The substantive $\mu \eta \delta \varepsilon$ is, which means nobody or no one, implies an absolute; it makes no exception to who should not be robbed; no person, no institution. The

${ }^{29}$ Walter Bauer, et. al., $\gg \delta ı \alpha \tau \dot{\sigma} \sigma \sigma \omega \ll$, A Greek English Lexicon of the New Testament and Early Christian Literature, 237-238. 
verb $\delta$ ı $\sigma \sigma \varepsilon i \omega$ means to $\gg$ extort money by force or threat of violence, shake violently or shake down $\ll{ }^{30}$ The verb $\sigma v \kappa o \varphi a v \tau \varepsilon \dot{\omega} \omega$ on the other hand means $\gg$ to put pressure on someone for personal gain, harass, squeeze, shake down, blackmail someone $\ll$, $\gg$ to secure something through intimidation and blackmail, extort $\ll$ (Luke 19:8). ${ }^{31}$ It is from this word that the English word 'sycophant' derives and means a swindler or extortionist. Since it is almost synonymous with $\delta\llcorner\alpha \sigma \sigma \varepsilon i \omega$, this last meaning is to be preferred here. Claus- $\mathrm{H}$ Hunzinger interprets the usage here as 'to oppress. ${ }^{32}$ Literally however, it colourfully means $\gg$ to make figs visible $\ll$, it was used in Athens to refer to those who provided information against those who exported figs from Africa. They were thus called 'fig showers. ${ }^{33}$ Each of these acts on the part of the soldiers amount to oppression, they are seen to use their position of strength to exploit the helpless citizens. Their profession, designed to provide safety and security to the people has now been abused, hijacked by them, and turned into a means of oppressing the same people they were employed to protect. John is teaching that no person or institution should be subjected to any of these abuses. Money should not be extorted from the people or embezzled from the coffers of the state; no person should be intimidated, blackmailed, or exploited.

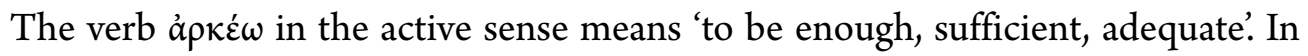

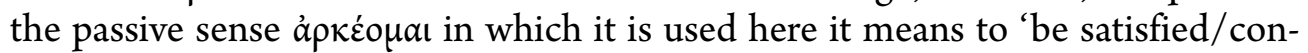
tent with something' ( 1 Tim 6:8).$^{34}$ ơ $\psi \omega$ ' viov means 'pay', 'wages' or 'provision'. It was considered among the ancients as the ration paid then to a soldier. ${ }^{35}$ It is the minimal required for frugal subsistence that may be determined independently of allowances. ${ }^{36}$ John teaches on the need to live within their means and not search for things beyond their reach. Even in the apparent insufficiency of their pay, they

${ }^{30}$ Walter Bauer, et. al., $\gg \delta ı \alpha \sigma \sigma \varepsilon i \omega \ll, A$ Greek English Lexicon of the New Testament and Early Christian Literature, 236.

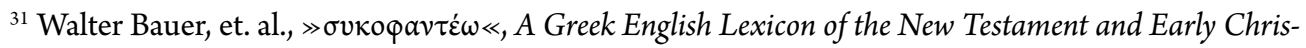
tian Literature, 955.

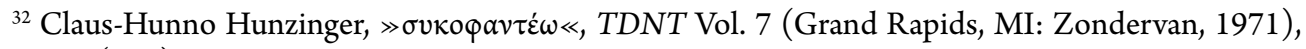
759 (759).

${ }^{33}$ R. Alan Culpepper, »The Gospel of Luke « in Leander E. Keck (ed.), The New Interpreter's Bible Vol. 9 (Nashville, TN: Abingdon Press, 1995), 3-490 (85).

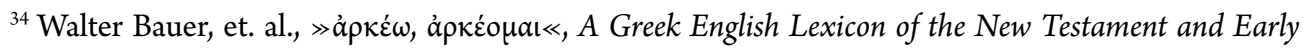
Christian Literature, 131-132.

${ }^{35}$ Walter Bauer, et. al., »ó $\psi \omega \dot{\omega} v ı v \ll$, A Greek English Lexicon of the New Testament and Early Christian Literature, 747; see also Chrys C. Caragounis, »ỏ $\psi \omega \dot{\omega} v ı v$ : A Reconsideration of Its Meaning «, Novum Testamentum 16.1 (1974), 35-57 (49).

${ }^{36}$ Hans Wolfgang Heidland, »ó $\psi \omega \dot{v} เ o v \ll$ in TDNT Vol. 5 (Grand Rapids, MI: Zondervan, 1967), 591-592 (592). 
are not to exploit others under that pretext; a just cause does not justify an unjust means. This too does not exonerate those who give insufficient pay to their employees rather it demands that to avoid the possibility of these corrupt practices, sufficient wages should be paid to workers.

The message of John to the soldiers is stricter than those of the publicans; this underscores John's assessment of the more exasperating and insolent nature of the soldiers' conduct. It is

$\gg$ a gentle rebuke for a depraved practice, a positive command after two negative ones; a going to the root of the matter (...), an attempt to rehabilitate ethically the bearers of force by teaching them not to covet other people's shoppings, but be, instead, satisfied with their own provisions. $\ll^{37}$

The teaching here underscores the importance of not abusing ones office, not extorting money or things from people, not embezzling public funds, not blackmailing people for the purpose of gaining cheap political gains. These are moral failings. It underscores the spirit of contentment as the basis, and antidote to these vices. Contentment does not necessarily imply lack of aspirations; rather it calls for moderation in every quest for better life. Every desire for improving one's economic or political fate is commendable but must be within the authorized limit of the law. John is calling on the soldiers to reintroduce justice and the rule of law into a system that is wrecked by injustice. The soldiers' question, which is emphasized

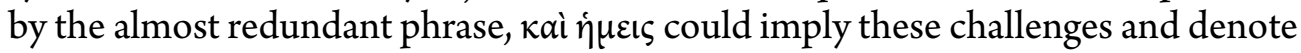
'even we' whose job exposes us to most uncharitable behaviours of contravening the Jewish piety. ${ }^{38}$

\section{Evaluation and Conclusion}

John the Baptist undertakes the religious mission of announcing and preparing his people for the arrival of the Christ. The coming of the Christ was a national expectation founded on the religiopolitical reality of his time. His preaching and teaching are in response to this age long expectation; and he addresses his audience in an extraordinarily incisive and prophetic manner. His teaching pricks and challenges his listeners to a decision. This decision comes in the form of ethical questions from the toll collectors and soldiers, which equally receive an ethical response from the Baptist. These two sets of law enforcement agents had taken advantage of their knowledgeable and authoritative positions in the society to exploit and extort from the citizens. In the exercise of their duties to the state, they were driven by greed

\footnotetext{
${ }^{37}$ Chrys C. Caragounis, »ó $\psi \omega \dot{v} v ı v$ : A Reconsideration of Its Meaning $\ll, 51$.

${ }^{38}$ I. Howard Marshall, The Gospel of Luke, 143.
} 
and egoism rather than by the conviction to offer sincere and selfless service to the fatherland. They allowed this cult of the self to overshadow their expected concern for the common good. Their sense of greed manifested itself in their lack of contentment with their genuine pay and possessions, and consequently drove them into flouting the law. The effects of this insensitivity were especially evident in the social discontentment among the citizenry and in the general apathy towards the toll collectors and soldiers in the court of public opinion. All of these constituted what may be regarded as corruption and its effects at the time.

The Baptist therefore uses his response to correct these anomalies and appeal to his listeners to be ethically upright as God's covenant people who seek renewal through the expected Messiah. The Baptist uses the occasion to address not necessarily how his questioners are to follow the laid down religious rites and rituals within and outside the temple. He rather seeks to bring them to the Christ from their daily secular realities and civic responsibilities. He addresses the theological question that is still relevant today on the relationship between the religious and the secular. How can one's life as a religious being and especially as a follower of Jesus be perceived and lived in the context of one's practical civic responsibilities? Can a Christian attain salvation independently of how he or she exercises his responsibility in and for the state? To these questions John responds by drawing the attention of toll collectors and solders to the fact that if they must embrace the Messiah, they must be accountable and law abiding in the exercise of their duties to the state by avoiding corruption. In other words, their duty to the state is equally a duty call from their religion and they are to assess their readiness for salvation in relation to how faithful they are in the exercise of their civic responsibilities to the state. Their lives must not move in a secular realm devoid of the presence of the holy, they must be open to transcendence and identify and propagate the sacred in their everyday experience as Christians. They must not restrict sacredness only to designated places, duties, and events. Corruption comes to play when this sense of the sacred is restricted and consequently absent from daily human experiences, encounters and activities in the society. It is a function of character and moral laxity that in turn demands character and moral transformation for a solution. ${ }^{39}$ The absence of the sacred in the daily human activities impoverishes human behaviours and deprives human actions of virtues. It is therefore an invitation to recover the sacred in every human commitment and service to the civil society. It is a recovery of the sacred in social contracts: an acknowledgement of the cosmic presence of Christ, and the sanctity of work for every Christian.

\footnotetext{
${ }^{39}$ Abiodun Simeon Ige, $\gg$ John the Baptist's Approach to Corruption: A Recipe for the Church in Africa «, Facta Universitatis: Law and Politics 14.4 (2016), 577-585 (585).
} 
The Lucan motif is principally on offering salvation to all, and salvation for Luke commences with the concrete experience of God's generosity here on earth, materially and spiritually. This salvation is felt among the community of believers > when charity and mutual sharing take place in daily life among people and when covetous exploitation is eliminated $\ll{ }^{40}$ It is this desire to make the resources of the society available to all that informs the Lucan Baptist's preaching about sharing with those who do not have and not exploiting others. The questions asked imply the desire to attain the salvation preached by John about the coming Messiah. John's answer implies that people's attitude towards their civic responsibilities have much to do in determining their salvation and defines sin. Salvation is not a utopia that is to be realized but a reality that is experienced here and now through the virtuous activities of men and women in the space accorded them by their society. By their virtuous activities on earth humans make salvation available to their neighbours in the here and now by creating and dispensing happiness among people. By acting thus, they prepare themselves for the future reward of eternal salvation. It is not about constructing the future, but the present, because it is the present that determines, and gives shape and meaning to the future.

The teaching is a combination of a prophetic-eschatological admonition, an invitation to compassion and justice, and a witness to the expected Messiah. The call to compassion and justice, otherwise described as social actions, is offered as an avenue for making the messianic salvation felt among fellow humans. When done, they equally become means for meriting the final realization of that salvation, which consists in eternal life. The Lucan Baptist therefore challenges today's religious institutions to be not only prophetic or involved in social actions, or worship and praise of Jesus. They are to combine both elements; their praise of the Messiah and their hope for eternity should motivate actions for the creation of a just, peaceful and equitable society where women and men will feel the presence of the Messiah with them. Religious bodies are to be not just prophetic and eschatological but equally and importantly and realistically involved with social issues and social reforms. It is about encouraging behaviours that express the God's purpose with the human community. It is the basis for judgment or assessment of the Christian worthiness or the moral life of a person in the sight of God. They are the natural consequences of lives centred on God who is merciful and just (Luke 6:36). They constitute the exemplifications and concretizations of the 'fruits of repentance' demanded in 3:8. It is a response of faith to God's visitation, which leads to God as conversion. Thus, to desist from the old ways is to convert and embrace a new way

${ }^{40}$ E. H. Scheffler, »The Social Ethics of the Lucan Baptist (Luke 3:10-14) «, Neotestamentica 24.1 (1990), 21-36 (32). 
of life commensurate with life as purposed by God. Consequently, these responses and the ethical teachings of the Baptist identified as fruits of repentance amount to conversion in the context of Lucan theology. It is a turning to God $\dot{\varepsilon} \pi \sigma \tau \rho \varepsilon \dot{\varepsilon \varepsilon v}$ that follows repentance $\mu \varepsilon \tau \alpha v o \varepsilon \tilde{v} v$ (Acts 26:20; 14:15). It is the expression of the positive aspect of the act denoted negatively by repentance, ${ }^{41}$ a renewal of personal relationship with God, which attracts and follows from a change in the inner attitude.

The ethical questions would not have been possible if John had not preached convincingly. God took the initiative of entrusting the Baptist with the responsibility of preparing people for the coming of the Messiah. The Baptist in turn cooperated with God. Luke is here indicating that the offer of salvation is dependent on the initiative of God » who not only sends out the word but also prepares the hearts of men and women to receive it $\ll .{ }^{42}$ It is Lucan theological direction also to indicate the important roles of humans in their cooperation with God for the divine offer of salvation; this is evident in Mary the Mother of Jesus and Joseph the foster father of Jesus in Luke 1-2. To bring people to the awareness of their wrongdoing in today's society, there is a need for the Church to be more effective in her prophetic mandate of preaching and calling people to repentance. To combat corruption, those who play the role of John the Baptist today must by their teaching and action be in a position to bring their listeners to the same pricked consciences, and consequently move them to seek the way out of their past ways by asking similar question. Like the Baptist, the Church and its sacred ministers must offer themselves as willing co-operators with God in his plan to transform the society from within through constant catechesis on the need to bring religious piety to bear on the exercise of civic responsibilities.

The advice of John constitutes an ethical teaching on corruption and underscores the peculiar challenges or misdemeanours associated with specific professions. It is not about stereotyping the toll-collectors and soldiers as the worst professions. It is rather an acknowledgement that every profession has circumstances that make room for abuses when not checkmated with the quest for decency and social responsibility or concern for the neighbours and the Christian spirit of righteousness. He does not invite people to abandon those professions but to be sincere and faithful to their duties and the requirements of the law establishing and guiding their profession. They are charged to bring God's justice and intents to bear on their sphere of work and influence, even if working under the authority of non-believers.

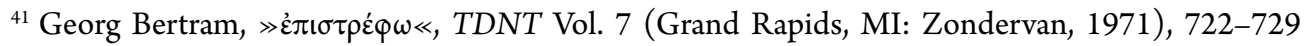
(727-728).

${ }^{42}$ I. Howard Marshall, Luke: Historian and Theologian $3^{\text {rd }}$ ed. (Downers Grove, IL: InterVarsity Press, 1983), 189.
} 
It is an invitation not to abandon a profession that is widely condemned as corrupt and unacceptable but to undertake the mission of transforming its socio-ethical wrongs with their religious ideals and turn it into an instrument for dispensing and attaining the messianic salvation. In this consists a civic conservatism, which acknowledges the need for Christians to accept the function and importance of the state and its organs in the day-to-day co-existence of citizens. This acceptance is to be guided by the mission to challenge and overturn the values of the social order with values of the Kingdom. ${ }^{43} \mathrm{John}$ is calling for an end to a lifestyle that is founded on greed and the acquisition of material possessions. He calls for justice and compassion in dealing with others, contentment in dealing with the self (v. 14), and charity (v. 11) in management and exercise of public offices. His warning against extortion sinks deep especially in a civil service and public service familiar with the habits of padding budgets. Citizens should live and act within the limits of their wages and the law and religious institutions must speak out against corruption and be exemplary in their conducts.

These ethical teachings of John follow and support the central theme of Luke's Gospel that: the kingdom of God has arrived. The pericope sets the tone for the Lucan theology of the Messiah coming to the aid of the oppressed in the hands of the powerful. Those in a position of authority are cautioned against using their position to exploit the innocent and helpless masses. It underscores, in the willingness of the toll collectors and soldiers to change, the concern of the Lucan Jesus for those condemned as unrighteous by public opinion.

${ }^{43}$ Jonathan Knight, Luke's Gospel (London: Routledge, 1998), 182. 


\section{ANTIKORUPCIJSKI STAV IVANA KRSTITELJA U Lk 3, 12-14}

\section{Christopher NASERI*}

Sažetak: Lk 3, 12-14 pripovijeda o odgovorima Ivana Krstitelja na pitanja carinika $i$ vojnika. Ti odgovori se u ovom radu tumače kao mjere protiv korupcije. Tekst stoga pruža uvid u neetičke prakse u novozavjetno doba i pokušaje vjerskih predstavnika da govore protiv njih. Koristeći sinkronijski pristup povijesno kritičke metode egzegeze, rad zaključuje da poruka Ivana Krstitelja daje uvid u razloge korupcije medu carinicima $i$ vojnicima iz doba Novoga zavjeta. Ti razlozi uključuju »neživljenje u skladu sa svojim mogućnostima $i$ i nepostupanje u skladu sa zakonom $\ll$. Ovaj rad potiče vjerske predstavnike da govore protiv korupcije i budu uzorni u svom ponašanju.

Ključne riječi: korupcija, Ivan Krstitelj, vojnici, carinici, etičko pitanje, građanska odgovornost, Evandelje po Luki, spasenje.

* Dr. sc. Christopher Naseri, Filozofski fakultet, Sveučilište u Calabaru, P. M. B. 1115 Calabar, Cross River State, Nigerija - Glavno sjemenište sv. Josipa, P. M. B. 1039 Ikot Ekpene, Akwa Ibom State, Nigerija, paxcasa@yahoo.com 